\title{
FEAR OF COMMITMENT: AN AFFLICTION OF ADOLESCENTS
}

\author{
PHILIP J. HARTER
}

\section{Consultation and Negotiation aRe an Integral PaRt OF THE ADMINISTRATIVE PROCESS}

Consultations and negotiations between agencies and affected interests are an essential ingredient of the administrative process if not of deinocracy itself. Their critical role has been recognized at least since the enactment of the Administrative Procedure Act (APA). ${ }^{1}$ In a now famous passage, the influential Attorney General's Manual on the Administrative Procedure Act explained in 1947 that

[t] he settlement of cases and issues by informal methods is nothing new in Federal administrative procedure. In its Final Report, the Attorney General's Committee on Administrative Procedure pointed out ... that "even where formal proceedings are fully available, informal procedures constitute the vast bulk of admimistrative adjudication and are truly the lifeblood of the administrative process."

Similarly, the Manual einphasized the importance of informal conferences (clearly the predecessors of advisory committees) and consultation in the regulatory process:

[I]nformal rule making procedure may take a variety of forms: informal hearings (with or without a stenograplic transcript), conferences, consultation with industry committees, submission of written views, or any combination of these. ${ }^{3}$

1. 5 U.S.C. $\S 551$ (1994).

2. U.S. DEP'T OF JUSTICE, ATTORNEY GENERAL'S MANUAL ON THE ADMINISTRATIVE PROCEDURE ACT 48 (1947) [hereinafter ATTORNEY GENERAL'S MANUAL], reprinted in ADMINISTRATIVE CONFERENCE OF THE U.S., FEDERAL ADMINISTRATIVE PROCEDURE SOURCEBOOK 97 (1985).

3. ATTORNEY GENERAL'S MANUAL, supra note 2, at 31. The Attorney General's Committee on Adininistrative Procedure was even more descriptive in assessing the role of negotiation in the development of new rules:

The practice of holding conferences of interested parties in connection with rule making introduces an element of give-and-take on the part of those present and 
These informal, unstructured processes were then used without much further development for the succeeding 25 years. Beginning in the 1970s, however, a number of factors combined to spark a renewed interest in the use of consultation and negotiation in the developinent of rules and other policies. With the emergence of the regulatory state, it became clear that these informal processes could result in horrible abuses. In the name of direct participation, the ability of some to participate in the regulatory process could effectively be extinguished and major governmental policies unduly influenced by narrow interests. Thus, if consultative procedures were to be used, safeguards had to be constructed to protect the integrity of the resulting decision. The process was suspect without them, and soine viewed it as illegitimate. At the same time, mediation began being used to resolve difficult environmental disputes, and structured negotiations were likewise employed in a variety of policy settings and got good results. ${ }^{4}$ These activities led to the developinent of a body of experience. Another major boost to the use of mediation came when John Dunlop, a well-known and experienced mediator of public disputes, became Secretary of Labor and advocated the use of the model that had proven so successful in the labor context as a method for making governmental decisions. ${ }^{5}$ Finally, the use of alternative dispute resolution was beginning to be discussed in legal circles as a ineans of facilitating the direct participation of parties in the resolution of issues to produce results that were both better and more widely accepted. ${ }^{6}$

In the early 1980s, the Administrative Conference of the United States (ACUS) ${ }^{7}$ promulgated the first of a series of recommen-
affords an assurance to those in attendance that their evidence and points of view are known and will be considered. As a procedure for permitting private interests to participate in the rule making process it is as definite and may be as adequate as a formal hearing. If the interested parties are sufficiently known and are not too numerous or too hostile to discuss the problems presented, conferences have evident advantages over hearings in the development of knowledge and understanding.

S. DoC. No. 77-8, at 104 (1941).

4. For a review of this experience, see Philip J. Harter, Negotiating Regulations: $A$ Cure for Malaise, 71 GEO. L.J. 1, 31-42 (1982). (1976).

5. See, e.g., John T. Dunlop, The Limits of Legal Compulsion, 27 LAB. L.J. 67

6. See, e.g., Frank E.A. Sander, Varieties of Dispute Resolution, Address at the National Conference on the Causes of Popular Dissatisfaction with the Adininistration of Justice (The Pound Conference) (Apr. 7-9, 1976), in 70 F.R.D. 79, 120-21 (1976) (discussing the benefits of mediation for parties in long-term relationships).

7. The Administrative Conference of the United States, known generally as ACUS, 
dations on the use of dispute resolution techniques-direct negotiations among the affected interests, mediation, arbitration, and coinbinations of these techniques, along with attendant procedures necessary to make them work. ${ }^{8}$ These recommendations sought to combine the benefits of Alternative Dispute Resolution (ADR) with procedures that would ensure the legitimacy of the resulting decisions; they were built on careful analysis and were vetted before ACUS's diverse membership. ACUS's recommendations thus developed the structure for the use of ADR by federal agencies. In addition, ACUS created a series of traming programs and seminars for agencies both to educate agency staff on the benefits of ADR and to instruct the staff on the successful use of the techniques in regulatory programs. It also afforded agencies the opportunity to share experiences.

Although under existing authority agencies were already using ADR procedures, particularly negotiated rulennaking, fairly regularly, the structured use of direct participation of the affected interests and other forms of ADR received a major boost when Congress enacted the Administrative Dispute Resolution Act (ADRA) ${ }^{9}$ and the Negotiated Rulennaking Act of $1990 .{ }^{10}$ Both acts amended the APA, and both lent Congressional imprimatur to the emerging use of ADR by federal agencies. ${ }^{11}$

The administrative use of ADR is therefore somewhere between fifteen and twenty years old-in the prime of adolescence. It is, therefore, appropriate to step back and assess both its current status and predict its likely future.

was charged by Congress to "study the ... administrative procedure[s] used by administrative agencies in carrying out administrative programs, and make recommendations to [appropriate bodies]." 5 U.S.C. $\$ 594$ (1994). Congress terminated ACUS by withdrawing all funding beginning November 1, 1995.

8. The first of this series was Administrative Conference of the U.S., Recommendation No. 82-4, Procedures for Negotiating Proposed Regulations (codified at 1 C.F.R. $\S$ 305.82-4 (1993)).

9. Pub. L. No. 101-552, 104 Stat. 2736 (1990) (codified as amended in scattered sections of U.S.C. tits. $5,9,28,29,31,41)$.

10. Pub. L. No. 101-648, 104 Stat. 4969 (1990) (codified in scattered sections of 5 U.S.C.).

11. Both acts contained sunset provisions; the Administrative Dispute Resolution Act expired five years after its enactment, in 1995 , see $\$ 11$, while the Negotiated Rulemaking Act was scheduled to expire in 1996, six years after its enactment, see $\$ 5$. 


\section{ADJUDICATORY USE OF ADR}

The use of alternative means of dispute resolution by federal agencies is now quite an expansive topic, ranging on both sides of the great divide of administrative law. On the adjudicatory front, we could analyze the efficacy of mediating major government contract disputes; the use of mediation in enforcement actions has been controversial, and its appropriate employment needs further refinement, but it is clearly growing. We could look at the use of mini-trials to resolve a range of issues, and, after the reauthorization of the 1990 Act by the Administrative Dispute Resolution Act of $1996,{ }^{12}$ we could speculate on the future use of binding arbitration..$^{13}$ As if these issues weren't enough, we could then delve into the role of Administrative Law Judges (ALJs) in providing this suite of services: Are ALJs a logical source of neutrals, ${ }^{14}$ or is one of the benefits of the growing range of procedures that are available to resolve specific issues the fact that the parties can now choose the one whom they will trust to help resolve their controversy?

Certainly the government's use of arbitration is not yet in its adolescent stage. The Administrative Dispute Resolution Act as originally introduced authorized agencies to use arbitration only if all of the parties consented specifically to its use. ${ }^{15}$ During the hearings leading up to passage of the ADRA, however, the Department of Justice (DOJ) argued that it would be unconstitutional for the United States government to use binding arbitration. ${ }^{16} \mathrm{Al}-$ though the analysis was not precise, DOJ's general argument was that only officers of the United States can make those decisions,

12. Pub. L. No. $104-320,110$ Stat. 3870 (1996) (codified as amended in scattered sections of U.S.C. tits. $5,28,29,41)$.

13. See 5 U.S.C. $\$ \S 575-581$ (1994) (authorizing administrative agencies to enter into binding arbitrations and enforcing the results of the binding arbitrations).

14. A "neutral" is defined by the ADRA as "an individual who, with respect to an issue in controversy, functions specifically to aid the parties in resolving the controversy." Id. at § 571(9). The neutral may serve as a convener, facilitator, mediator, arbitrator, or in some other position; the term "neutral" is commonly used to refer to the position generically as one who is disinterested in the outcome of the controversy.

15. See Administrative Dispute Resolution Act of 1989: Hearing on S. 971 Before the Subcomm. on Oversight of Government Management of the Senate Comm. on Governmental Affairs, 101st Cong. (1989) [hereinafter ADRA Hearings]. Specifically, the ADRA prohibits making arbitration agreements a condition of a government contract or other benefit. See 5 U.S.C. § 575(a)(3) (1994).

16. See ADRA Hearings, supra note 15, at 13 (statement of William P. Barr, Assistant Att'y Gen., Office of Legal Counsel). 
and an arbitrator would generally not be appointed by the requisite means. ${ }^{17}$ The American Bar Association, having adopted a resolution supporting the use of arbitration by administrative agencies, testified in support of the arbitration provisions and disagreed with DOJ's theory. ${ }^{18}$ To reach closure, however, a compromise was fashioned by which an agency could agree to binding arbitration but the award would not becorne final for a period of thirty days. During this thirty-day period, the head of the agency, who holds a non-delegable personal duty, could vacate the award and thereby nullify it; if the award was vacated, the agency would pay attorney's fees. Further, to reduce the appearance of impropriety of trial counsel seeking "two bites at the apple," the principle of separation of functions would apply to the agency head's review. ${ }^{19}$ As a result of the opt-out provision, private parties were simply unwilling to use the arbitration, and the mere existence of the override seemed to taint the use of ADR under that Act-it was as if there were a hole in the ice and everyone knew to stay away from the danger zone.

Subsequently, in a inore exphicitly considered, formal opimion, Assistant Attorney General for the Office of Legal Counsel Walter Dellinger determined that binding arbitration would indeed be constitutional. ${ }^{20}$ Although DOJ initially testified at the ADRA

17. See id.

18. See id. at 28-38 (statement of Philip J. Harter on behalf of the American Bar Association). The ABA testified that, under current law, an arbitrator would not be regarded as a "principal" officer of the United States, and, thus, does not require Presidential appointment, since all of the factors that caused the Supreme Court to hold that an independent prosecutor is not a "principal" officer of the United States likewise are met by an arbitrator. See id. at 30; see also Morrison v. Olson, 487 U.S. 654, 670-73 (1988) (holding that it does not violate the Appointments Clause for Congress to vest the power to appoint an independent counsel in the Special Division court created by the Ethics in Government Act because independent counsel appointees are "inferior" officers in that: 1) the Attomey General is authorized to remove them; 2) they have limited duties; 3) they have limited jurisdiction; and 4) they are temporary).

19. See 5 U.S.C. $\$ 580(\mathrm{c}),(\mathrm{g})(1994)$.

20.

You have asked for our opirion as to whether the Constitution in any way limits the authority of the federal government to submit to binding arbitration. Specifically, you have asked us to explain and expand on advice we issued on September 19,1994, in which we confirmed our earlier oral advice that "the Office of Legal Counsel no longer takes the view that the Appointments Clause, U.S. Const. art. II, § 2, cl. 2, bars the United States from entering into binding arbitration." ... Below, we reiterate this conclusion and, pursuant to your request, set forth the reasoming by which we reached it. In addition, we consider, again pursuant to your request, the various other constitutional provisions that may be implicated when the federal government enters into binding 
reauthorization hearings that it preferred to retain the override, it subsequently changed its position and did not oppose the authorization of agencies to engage in binding arbitration. ${ }^{22}$ Congress embraced the concept in its final legislation ${ }^{23}$ so that agencies were authorized to enter into agreements which call for the use of binding arbitration to resolve issues in controversy. Arbitration might be expected to be used in at least three situations: the resolution of straightforward government contract claims; cases where the facts are not complex and the value is not significant to any party; and the resolution of issues that arise on an ongoing basis in the implementation of an agreement or contract. ${ }^{24}$

While it has been retooled and its attractiveness enhanced at least for private disputants, arbitration is in its infancy. Like an infant's, arbitration's future is full of hope and promise, but without sufficient experience to get the type of reading one can of an adolescent-pimples and all.

The ADRA also encourages agencies to use mediation and other consensual forms of dispute resolution to resolve issues in controversy. It clarifies the confidentiality provisions in an atteenpt

arbitration. We conclude that none absolutely bars the federal government from taking such action.

Memorandum from Walter Dellinger, Assistant Att'y Gen., U.S. Dept. of Justice, to John Schmidt, Associate Att'y Gen., U.S. Dept. of Justice, regarding Constitutional Limitations on Federal Government Participation in Binding Arbitration (Sept. 7, 1995) (on file with Duke Law Journal) (citation and footnotes omitted).

21. See ADRA Hearings, supra note 15, at 13 (statement of William P. Barr, Assistant Att'y Gen., Office of Legal Counsel).

22. See Prepared Statement of Peter R. Streenland, Jr., Senior Counsel, Office of Alternative Dispute Resolution, Dep't of Justice, Before the House Judiciary Comm. Subcomm. on Commercial \& Admin. Law Concerning the Admin. Dispute Resolution Act Federal News Serv., Dec. 13, 1995, available in LEXIS, Nexis Library, Curnws File (discussing how DOJ is not opposed to removing the opt-out provision); see also 142 CONG. REC. H5787 (daily ed. June 4, 1996) (discussing how a DOJ official testified in favor of repealing the override).

23. To ensure that runaway arbitrators do not "break the bank," the ADRA requires that the arbitration agreement must also specify the limits of the award. See 5 U.S.C.S. \& 575(a)(2) (Law Co-op. Supp. 1997). Thus, the arbitrator's authority is appropriately corralled.

24. For example, the Forest Service might settle a case brought by an environmental group about the management of a particular forest. The settlement agreement might call for certain actions to be taken over the course of five years; the agreement might also provide that any disagreements over its implementation would be submitted to arbitration. Through arbitration, the issues could be quickly resolved by a person with first-hand, onthe-ground knowledge of what is happening. Arbitration can also be used, as is typical in the private sector, to resolve construction disputes as they arise. 
to strike a delicate balance between the openness that ensures the integrity of agreements and the level of confidentiality that is necessary if they are to be reached. ${ }^{25}$ To this end, Congress resolved the potential tug between the ADRA, which prohibited disclosure by a neutral of confidential information, ${ }^{26}$ and the Freedom of Information Act (FOIA), ${ }^{27}$ which could require its revelation if the neutral were a government official. Congress determined that a communication between a neutral and a party that is confidential under the ADRA is also exempt from FOIA. ${ }^{28}$ This ambiguity had inhibited the use of government neutrals in dispute resolution. ${ }^{29}$

Some agencies expressed reluctance to use an explicit form of mediation to resolve multiparty issues, fearing that those assembled to develop an agreement might be regarded as an advisory committee and hence the whole process would be required to be conducted under the Federal Advisory Committee Act (FACA). ${ }^{30}$ The Clinton administration took a hard line on establishing new advisory committees, and even if they could be approved, it some-

25. See Administrative Dispute Resolution Act of 1996, Pub. L. No. 104-320, § 3, 110 Stat. 3870, 3870 (1996).

26. See Administrative Dispute Resolution Act of 1990, Pub. L. No. 101-552, § 584, 104 Stat. 2736, 2740-41 (1990).

27. See 5 U.S.C. $\S 552(1994)$.

28. See 5 U.S.C. $\$ 574(j)$ (1994). It should be noted that this explicit protection does not extend to communications among the parties. Discussion among the parties, however, is closely akin to settlement negotiations without a mediator. Because there is no particular reason why those discussions should be accorded any different treatment from that provided to unassisted settlement negotiations, they are treated the same as other settlements. The conference committee made clear that a communication would be regarded as being between two parties in a situation where a party gives a document to a neutral who in turn provides it to another party. Since the neutral acts only as a conduit, Congress felt this type of commumication should not be covered by the exception. See 142 CONG. REC. H11,110 (daily ed. Sept. 25, 1996) (Joint Explanatory Statement of the Committee of Conference). The ADRA further provides that documents that are available to all the parties are not covered by its confidentiality provisions. See 5 U.S.C. $\$ 574($ b)(7) (1994). But, to facilitate the administrative use of early neutral evaluation and other similar settlement techniques when a neutral furnishes all of the parties with a proposal, the Act also protects instances where the neutral generates a document that is provided to all the parties. See 5 U.S.C.S. \& 574(b)(7) (Law Co-op. Supp. 1997); see also 142 CoNG. REC. H11,448 (daily ed. Sept. 27, 1996) (statement of Rep. Reed) (discussing exemptions from FOIA provided for under the statute).

29. There is a fairly broad use of government personnel, known as the "Shared Neutrals Program," to help resolve internal EEO disputes. See 136 CoNG. REC. H12,968 (daily ed. Oct. 26, 1990) ("An agency may use the services of one or more employees of other agencies to serve as neutrals in regulatory proceedings.")

30. Pub. L. No. 92-463, \& 1, 86 Stat. 770 (1972), reprinted in 5 U.S.C. app. (1994). 
times took six unonths or more for the paper to wind its way to approval and establishment of the committee. ${ }^{31}$ As a result, agencies were understandably nervous about doing anything which might ensnare them in that bureaucratic nightmare. So agencies simply avoided the bureaucracy by going underground, by not using a proven techmique to resolve contentious issues, or by simply not trying to reach consensus at all. Congress tried to address this situation in two ways. First, it directed the Office of Management and Budget (OMB) to "take appropriate action to expedite the establishment of . . . committees estabhished to resolve disputes under the Administrative Dispute Resolution Act."32 Second, Congress directed OMB to study the potential for eliminating "any redundant administrative requirements related to filing a committee charter ... and providing public notice" of the intent to form negotiated rulemaking committees. ${ }^{33}$ The reason Congress gave for not making a similar directive with respect to committees established under the ADRA is that FACA simply does not apply to them..$^{34}$

Although I have not done any systematic survey or accounting, general observation and the Washington scuttlebutt suggests that the use of consensual processes to resolve adjudicatory disputes is indeed sohdly in its adolescence; ${ }^{35}$ there is currently more talk about using ADR than actual widespread use. But ADR processes are now accepted ineans for addressing these issues: they

31. For a description of one agency's travail, see 142 CONG. REC. S6159 (daily ed. June 12, 1996) (statement of Sen. Johnston).

32. Administrative Dispute Resolution Act of 1996 , Pub. L. No. 104-320, § 11(e), 110 Stat. 3870, 3874 (1996).

33. Id. The theory is that the formal notice of intent that is to be published in the Federal Register would serve as the committee charter so that one document could serve both purposes.

34. "It is the understanding of the Managers that the Federal Advisory Committee Act (FACA) applies to proceedings under the Negotiated Rulemaking Act, but does not apply to proceedings under the Administrative Dispute Resolution Act." 142 CONG. REC. H11,110 (daily ed. Sept. 25, 1996) (Joint Explanatory Statement of the Committee of Conference).

35. The DOJ has established an Office of Dispute Resolution. The duties of the office include clarifying the use and applicability of ADR. Because DOJ had always been seen as somewhat reluctant to embrace ADR, its action in establishing this office and its subsequent activities may send an important signal to other parts of the DOJ and other administrative agencies. Indeed, the Attorney General encouraged the increased use of ADR in a speech to the American Bar Association at its mid-year meeting, in January 1997, in San Antonio, and in a speech to the Society for Professionals in Dispute Resolution in Los Angeles in October 1996. 
are not alien; they are not regarded as somehow in derogation of "real" procedure; they are not viewed (at least as much as they once were) as "giving away the store;" and hitigants seem to understand and accept them with increasing frequency. Thus, it looks like this adolescent lias a promising future.

The ADRA for the first time also authorizes agencies to use "ombuds" as a form of dispute resolution. ${ }^{36}$ In addition, the Small Business Regulatory Enforcement Fairness Act of 1996 (SBREFA) also requires agencies to establish ombudsmen to help resolve regulatory matters. ${ }^{37}$ Ombudsmen liave been widely used in Europe for decades and their use in the Urited States lias been considered on multiple occasions, ${ }^{38}$ it appears that the concept may finally be taking root in the United States. Indeed, many of the horror stories about regulation run amok that were raised in the floor debates on the comprehensive regulatory reform legislation during the last term of Congress were not in fact problems with either a statute or implementing rule but rather were difficulties stemming from their enforcement in the field-precisely the type of issue that might best be addressed by an ombudsman. Although in incubation for a generation, this approach to regulatory

36. See Administrative Dispute Resolution Act of 1996, Pub. L. No. 104-320, § 2, 110 Stat. 3870,3870 (1996). There is some confusion over the term "ombudsman" or, the gender neutral version that Congress employed, "ombuds." The classical use of the term means an independent government official who receives complaints against government agencies, who imvestigates the situation, and if merited, makes recommendations to remedy the complamts. In this way, an ombudsman might be available to resolve conflicts or other matters between a private citizen and the agency. In some instances, however, the term has come to refer to someone who helps resolve issues, usually pertaining to employment in an agency; these are sometimes known as "internal ombudsmen."

37. See 15 U.S.C.A. \& 657 (West Supp. 1997).

38. See, e.g., Administrative Conference of the U.S., Recommendation No. 90-2, The Ombudsman in Federal Agencies, 1 C.F.R. § 305-90-2 (1993); WALTER GELLHORN, When americans Complain: Governmental Grievance Procedures 57 (1966) (discussing the workload of Congressmen); WALTER GELLHORN, OMBUDSMEN AND OTHERS: Citizens' Protectors in Nine Countries 1-5, 438-39 (1966) (describing the use of ombudsmen in seven European countries); SAM ZAGORIA, THE OMBUDSMAN: HOW GOOD GOVERNMENTS HANDLE CITIZENS' GRIEVANCES 68 (1988) (noting imterest in ombudsmen expressed by American professional organizations and describing grants made by the federal Office of Economic Opportumity so that states and cities may study the possibility of establishing an ombudsman's office); David R. Anderson \& Diane M. Stockton, Ombudsmen in Federal Agencies: The Theory and Practice, 112-122 (1990) (report for ACUS) (describing the adoption of ombudsmen programs in Scandinavia and summarizing the history of American interest in ombudsmen). 
issues is clearly in its infancy and developments surrounding the regulatory use of ombudsmen merit careful attention.

Much is happening with regard to the use of ADR in adjudication. On the other side of the dichotoiny, even more developments are taking place.

\section{The Use of Consensus In Policymaking}

A wide array of techniques has arisen in the past 15 years by which agencies consult with or otherwise involve the public in making policy-related decisions. ${ }^{39}$ Appendix A sets out those used by the Environinental Protection Agency (EPA). The first column is comprised of techniques the agency uses to consult with members of the private sector to enhance the parties' understanding of the situation. In these processes, at least one side will be providing information to the other, and often there will be a structured exchange of views. The participants are not expected to reach any agreement and, indeed, none is achieved. Such discourses are referred to generically as "information exchanges." The second column reflects a more ambitious enterprise in which the agency discusses an issue or set of issues with the expectation that the participants will reach a general agreement on recommendations to the agency. But-and this is critically important-it is clear that no one is "bound" by the decision and that the agency will flesh out any resulting advice. They are, in short, recommendations. These techniques are often referred to as "policy dialogues" or simply as "advisory committees." In the final column are consensus decisions: The parties reach a specific agreement to which each party, including the agency, is expected to adhere.

39. Because of their more informal procedure, states often used direct negotiations and other forms of consultation earlier and more frequently than federal agencies. They lagged, however, on the use of structured forms of ADR. States now appear to be using such techniques in a variety of settings, including negotiated rulemaking and conferences to develop legislation. See, e.g., CENTER FOR PUBLIC POLICY DISPUTE RESOlution, TEXAS NEGOTIATED RULEMAKING DESKBOOK (1996); WASHINGTON STATE OFFICE OF Financial Management, A Guide to Public InVolvement in RULe Making (1995). Vermont has used a form of negotiated rulemaking for tackling some of its most difficult environmental issues, such as solid waste disposal and noise pollution. The South Coast Association of Governments (SCAG) in Califormia is about to embark on a reg neg to "develop a process in which air quality emissions credit may be given for nonregulatory or voluntary ineasures." Letter from Helene V. Smookler, ADR Coordinator, SCAG, to Philip J. Harter (Apr. 1997) (on file with author). 
EPA has touted its variety of new forms of public involveinent. Its Common Sense Initiative (CSI) is an industrial sector-bysector endeavor among various stakeholders to find ways to develop cleaner, cheaper, and smarter approaches to environmental management than the medium-by-medium approach of the existing environmental statutes. ${ }^{40}$ EPA describes its regulatory remvention initiative, Project $\mathrm{XL}$, as "offer[ing] potential project sponsors and co-sponsors the opportunity to develop and implement alternative strategies that produce superior environmental performance, replace specific regulatory requirements, and promote greater accountability to stakeholders;, but without particular detail, on stakeholder imvolveinent in the process. In addition, EPA has made many public statements about its use of consensus im such areas as "Brownfields."

This general explosion of applications alone indicates a search for new forms of participation in the regulatory process. The mere existence of this range of approaches indicates a coming of age of the quest to involve the public in regulatory decisions. Perhaps this signifies a robust inaturity. But, perliaps, in keeping with our metaphor, our adolescent merely underwent a growth spurt and is now at an awkward stage. To decide whether this profusion of processes is good, bad, or ugly requires a further analysis.

The inost well developed of these techniques, other than the public hearings and meetings that are adjuncts of the APA itself,

40. For a list of sources discussing the EPA's Common Sense Initiative, see THE SCIENTIFIC CONSUlting GROUP, INC., REVIEW of THE COMMON SENSE INITIATIVE app. A (1997) [hereinafter CSI REVIEW].

41. Regulatory Reinvention (XL) Pilot projects, 62 Fed. Reg. 19,872, 19,877 (1997); see also Regulatory Reinvention (XL) Pilot Projects, 60 Fed. Reg. 27,282, 27,282-83 (1995) (earlier version of same).

42. These are industrialized areas that do not meet current EPA standards, but nonetheless are marketable for developinent or for other economic use. In such situations it is important to consider the best metlood for developing the site given its non-complying status. The question, therefore, is whether there are ways to develop the site without full compliance witl specific numerical requirements while still providing the requisite level of protection and making it feasible, perliaps even attractive, to put the parcel to use instead of leaving it abandoned. The neighbors, lending institutions, business interests, environmental interests, and the environmental regulatory agencies each have a stake in those decisions. See, e.g., Announcement of Application Deadline for the Competition for the 1997 National Brownfields Assessment Denionstration Pilots, 61 Fed. Reg. 56,953, 56,953 (1996); Carol Browner, Brownfields Agenda: Solving An Urban Pollution Problem, WASH. POST, Apr. 22, 1996, at A14 (discussing President Clinton's Brownfields Action Agenda and advocating the passage of new legislation to encourage the cleaning of abandoned and contaminated land). 
is negotiated rulemaking (reg neg). ${ }^{43}$ Fifteen years ago, when the theory of negotiated rulemaking was just emerging, I predicted a number of major benefits from the practice. ${ }^{44}$ Among them was the fact that the parties would be able to participate directly and immediately in the decision, thereby providing a legitimacy that is missing from hybrid rulemaking. In addition, the costs of developing the rule may be lower since the parties would not have to engage in as much adversarial research and positioning. The parties could focus on the issues that actually separate them and on the issues of importance to them. "Rulemaking by negotiation can reduce the time and cost of developing regulations by emphasizing practical and empirical concerns rather than theoretical predictions." 45 The parties have the experience and ability to focus on the details necessary to make a rule work day-to-day in the field. Interestingly, the lack of judicial review was not advocated as a prime benefit. It would be a likely ancillary benefit of the parties' mutual acceptance of the rule and its ensuing legitimacy, but was not an end in itself.

Such were the predictions before any reg negs were actually undertaken. Formal evaluations are extraordinarily expensive and face the difficulties inherent in making counter-factual predictions (i.e., what would have happened if some other process were used to develop the rule), or finding a suitably analogous rule with which to compare a given proceeding. ${ }^{46}$ As a result, few formal evaluations have been conducted, so that it is difficult to deter-

43. Perhaps illogically, negotiated rulemaking goes by the shortened name of "reg neg." The reason for the apparent reversal of terms is that initially the term used to describe the process of negotiated rulemaking was "regulatory negotiation," but eventually "negotiated rulemaking" became the more widely accepted term. See, e.g., Regulatory Negotiation: Joint Hearings Before the Senate Select Comm. on Small Bus. and the Subcomm. on Oversight of Gov't Management of the Senate Comm. on Governmental Affairs, 96th Cong. 138 (1980) (statements of Jeffrey H. Joseph, M. Kendall Fleeharty, and Mark Schultz, U.S. Chamber of Commerce) (referring to regulatory negotiation commissions as "reg neg" commissions).

44. See Harter, supra note 4 , at $28-31$.

45. Id. at 30 .

46. It is always difficult to determine what would have been done if what actually was done had not happened. For example, if an individual purchases a new car, it is virtually impossible for him to determine, three years after the fact, exactly what lie would have done with that money had he not bought the car, or whether he would have been worse off financially had he used the money differently. The same is true when a reg neg is used, for it is likewise virtually impossible to determine if less expensive or more effective means could have been employed to resolve the problem. 
mine in a rigorous way the extent to which the theory has been borne out.

One major evaluation has been undertaken to compare negotiated rules at the EPA with those developed by the traditional notice-and-comment process. The study is currently being conducted for the EPA by Cornehus M. Kerwin, Dean of the School of Public Affairs at American University and Professor Laura I. Langbein. They have released a draft report of their analysis of the reg neg portion of their study. ${ }^{47}$ Their initial conclusions include:

Based on the data presented above, negotiated rulemaking is successful on several critical dimensions. It is widely perceived by participants as an effective means for developing regulations on virtually all important qualitative dimensions. The criteria estabhished in literature and law for the selection of candidates for reg neg appear to be relevant in the selection process used by EPA, altliough their importance appears to vary from case to case and the discretion exercised by key Agency officials in the use of techniques is obviously considerable. The opportunity to participate in the process appears to be extended broadly, albeit not universally, and EPA or the facilitator it secured were frequently identified as an imitiator of participation.

The process of negotiation itself einerges as a very powerful vehicle for learning what the participants in the process value lighly, and there are many types of information that is exchanged. The interviews suggest further that what is learned has long-term value and is not confined to a particular rulemaking.... The negotiation process employs a nuniber of devices to subdivide issues, such as working groups and caucuses, that were viewed as effective by a substantial number of respondents. And the use of non-committee observers serves as a device to expand participation without inflating the negotiating groups past workable limits. Facilitators were generally viewed as competent, unbiased and providing a number of services that proinoted consensus.

47. See generally CORNELIUS KERWIN \& LAURA LANGBEI, AN EVALUATION OF Negotiated RULEMAKING at THE ENVIRONMENTAL PROTECTION AGENCY: PHASE I (1995) (report prepared for ACUS) [hereinafter KERWIN \& LANGBEIN]. The report was originally conducted for the EPA and ACUS, until funding for the latter was withdrawn. See supra note 7. 
Most participants believe their participation had a substantial effect on the agreement that was produced and report that the opportunity to have an impact on the outcome was one of the aspects of the process they considered most valuable. ${ }^{48}$

Moreover, a careful review of the experience with negotiated rulemakings indicates that those predictions have, imdeed, been realized in diverse settings. ${ }^{49}$ Negotiated rulemakings have been used by agencies to develop rules they knew would be controversial but which were required by statute to be issued in a very short period and for rules for which the customary notice-andcomment process simply had not worked. EPA's Clean Fuels reg neg developed the basis for reformulated gasoline and its surrounding regulatory requirements in an astonishingly short period given the magnitude of the task and the potential costs that the resulting rule would likely impose..$^{50}$ So, too, the Coast Guard turned to reg neg when it became clear that the controversies surrounding its vessel response plans meant that the rule would probably not be issued in time to meet a critically important statutory deadline that had enormous financial implications if the date were missed. The committee, an international set of representatives, was able to craft a notice of proposed rulemaking ${ }^{51}$ that was published just seven months after the notice of intent to form the committee appeared, ${ }^{52}$ the rule went into effect in another seven months. ${ }^{53}$ In some instances, the reg neg committees have

48. Id. at 34 .

49. Appendix $B$ uses the list of negotiated rulemakings prepared by Professor Coglianese but adds comments that explain particular aspects of some of them. See Cary Coglianese, Assessing Consensus: The Promise and Performance of Negotiated Rulemaking, 46 DUKE L.J. 1255, 1281 tbl.3 (1997). Those comments illustrate what follows in the text.

50. See Regulation of Fuels and Fuel Additives: Standards for Reformulated and Conventional Gasoline, 59 Fed. Reg. 7716 (1994) (codified at 40 C.F.R. pt. 80 (1996)). Professor Coglianese correctly points out that the rule was ultimately changed and then subjected to judicial review. See Coglianese, supra note 49, at 1290-92. Even though the committee reached an agreement across the board, no rulemaking is immune from presidential politics, and EPA changed the rule at the direction of the White House late in an election year when pressured by a particular interest. The product of the reg neg still provides the main basis for the rule that has had a significantly beneficial effect on air pollution in our major cities.

51. See Vessel Response Plans, 57 Fed. Reg. 27,514 (1992) (proposed June 19, 1992).

52. See Vessel Response Plans and Carriage and Inspection of Discharge-Removal Equipment, 56 Fed. Reg. 58,202 (1991) (notice of intent to form a negotiated rulemaking committee published Nov. 18, 1991).

53. See Vessel Response Plans, 58 Fed. Reg. 7376 (1993) (codified at 33 C.F.R. pt. 
been able to develop rules in a relatively expeditious time when the issues have been languishing on the agency's dockets for years-precisely because the agency has not been able to resolve the underlying controversies. ${ }^{54}$ And, in one of the few instances in which a negotiated rule was closely analogous to a rule developed by traditional ineans, the negotiated rulennaking took only half as long to draft the rule and cost only half as inuch. ${ }^{55}$

The rules that emerge through reg neg reflect a shop-floor insight and expertise. Hence, they can develop considerable innovation and take account of issues that would likely escape the attention of an agency in a traditional rulennaking. EPA's equipment leak standard is such an example. ${ }^{56}$ So is the steel erection standard: ${ }^{57}$ the committee identified a vast number of issues that would greatly improve safety beyond the relatively narrow set of issues imitially foreseen by the Occupational Safety and Health Administration (OSHA) ${ }^{58}$

Interestingly, there is some mdication that rules that emerge from reg negs are more stringent than those the agency would

155 (1996)). That interim final rule was later incorporated into a broader set of rules, but that does not diminish the fact that the committee produced a rule that went into effect as scheduled.

54. For example, when OSHA's steel erection negotiated rulemaking advisory committee (SENRAC) was able to craft a standard governing the construction of steel structures-by far the greatest safety risk OSHA regulates-in about 18 months even though the issue had been on OSHA's docket for two decades! (Requests for clarification of the existing Subpart $R$ were submitted in 1974; OSHA began drafting a proposed rule for Subpart $R$ in 1984 and submitted it to its standing advisory committee for comment). During that period, OSHA had atteinpted, unsuccessfully, to issue a Notice of Proposed Rulemaking.

55. Telephone Interview with James M. Estep, Office of the Solicitor, U.S. Dep't of Labor (May 1997) (discussing OSHA's Methylenedianiline (MDA) and 1, 3-Butadiene standards).

56. Chemical plants, like houses, can develop drippy faucets; it is desirable to keep the leaks to a minimum, especially when they release toxic chemicals. This standard imposed requirements to test and fix valves to reduce the emission of toxic chemicals. It is true, as Professor Coglianese points out, that nearly three years elapsed before the consensus was published as a final rule. That is because it was a part of EPA's Hazardous Orgaric NESHAP (National Emission Standard for Hazardous Air Pollutants) under section 112 of the Clean Air Act of 1990, and the equipinent leak portion had to await completion of the other parts before it could become final. Meanwhile, however, there was testimony that many firms were complying with the standard long before required to do so.

57. See 29 C.F.R. $\S 1926.105$ (1997).

58. See 62 Fed. Reg. $21,966-67$ (1997) (discussing how negotiated rulemaking greatly improved the steel erection standard rulemaking process). 
have been able to issue on its own; nevertheless, these rules are cheaper to implement precisely because the committee can focus on ways to get the greatest return. As for judicial review, there has never been a judicial challenge to a negotiated rule where the agency issued the rule as negotiated and the parties agreed not to challenge it. ${ }^{59}$

Unlike other forms of administrative procedure, reg negs and other means of consensus building have few fixed rules. Their hallmark is their flexibility: they are highly adaptive and can be modified to take account of changing circumstances. While pliable, they are not formless. The benefits of negotiated rulemaking have resulted from a careful attention to detail and a few fundamental precepts. Since both the integrity of the process and its success turn on their observance, it is worth emphasizing them here.

\section{A. Convening}

The Negotiated Rulemaking Act contemplates that a relatively comprehensive inquiry will precede a decision to empanel a committee. ${ }^{60}$ The purpose of this inquiry is to identify: the interests that would be affected by the rule; the issues that need to be resolved in the rulemaking; the information that is needed to resolve those issues; and to determine whether the conditions described in the Act that have been developed to predict whether or not the committee will reach closure have been met. This is a critically important phase of every negotiated rulemaking.

Anyone convening the negotiating committee needs to recognize that the committee will be engaged in a very democratic process. In the normal democratic process, each person is represented by a representative elected from a regional area. This rep-

59. The only case that actually discusses the judicial review of a negotiated rule is USA Group Loan Services, Inc. v. Riley, 82 F.3d 708, 714-15 (7th Cir. 1996) (discussing student loan servicers' complaint that the Department of Education violated the process by negotiating in bad faith). Although it is not entirely clear from the court's opinion, it appears that either the committee did not reach agreement or the agency's rule is not fully consistent with an agreement if one existed. For a criticism of Judge Posner's lack of understanding of negotiated rulemaking, see Philip J. Harter, First Judicial Review of Reg Neg A Disappointment, 22 ADMIN. \& REG. L. NEWS, Fall 1996, at 1, 1, 12. Another case involving the judicial review of a set of negotiated rules is Career College Ass' $n v$. Riley; the court, however, only mentions that fact in passing, and from its discussion, it surely appears that the rules that emerged were not the product of consensus. See 74 F.3d 1265, 1267 (D.C. Cir. 1996).

60. See 5 U.S.C. \$ 563(a) (1994). 
resentation has nothing to do with interests or common views on an issue but is instead based solely on geography. ${ }^{61}$ Each representative must distill competing views within the geographic area, and cannot really be expected to represent a particular interest fully in a matter. The underlying purpose is to ensure that each person who is interested in the matter can somehow be represented. The committee needs what mathematicians refer to as a "covering space"-a collection of sets such that each member of the space being covered belongs to at least one of the sets. One way of doing that would be to use interest as the assigning variable: each affected party is entitled to be represented in the deliberations and decision by means of its interest in the outcone. The organizing principle, therefore, is the differentiation of interests, not of areas. The outcome, however, is the same: everyone is represented.

As law professors love to point out, it is impossible to achieve this breadth of representation in practice; not every narrowly defined, specific interest is in fact represented at the table..$^{62}$ But, a proper convening does ensure that there are enough diverse general interests effectively represented at the table so that the major issues will be fully and fairly raised, discussed, and negotiated. ${ }^{63}$ Moreover, a convening is a form of outreach in which the agency actively seeks diverse representatives to take part in the development of the rule from its infancy. As a result, a far greater range of interests actually participates in the rule than in customary notice-and-comment rulemaking where the agency passively receives comments. ${ }^{64}$ For example, in one recent convening the agency was asked to list the interests that would need to partici-

61. As we have seen from our political history, districts can, of course, be doctored to ensure that they represent some sort of value shared by a majority, such as political viewpoint or racial preferences.

62. See, e.g., Susan Rose-Ackerman, Consensus Versus Incentives: A Skeptical Look at Regulatory Negotiation, 43 DUKE L.J. 1206, 1210 (1994) (stating that while reg neg participants must be similarly well-organized, knowledgeable, and skillful, there should not be too many distinct groups).

63. In continuing the mathematical analogies, the representatives need to "span the space," so that any other interests can be made up of combinations of those representatives. That would be the case, for example, if the diversity of interests were such that one could be confident that all the major issues would be raised by someone on the committee.

64. Why is it that those same law professors who raise convening concerns with respect to negotiated rulemaking do not seem bothered by the lack of diverse representation among the comments in traditional rulemaking? 
pate in a negotiated rulemaking, and after internal consultation it produced a dozen. By the time the convening was completed, the list had doubled; many more interests were identified that could provide insight imto the issues under discussion. ${ }^{65}$

In addition to selecting the parties, the convening also defines the issues that need to get resolved. The discussions with those who have a direct, firsthand insight into what is happening often-indeed almost always-play a crucial role in defining the issues that need to be resolved. For example, in EPA's equipment leaks reg neg, the agency initially proposed to negotiate the conversion factors that are used to translate the volume of chemicals being processed into estiniates of air emissions. The convening revealed that the parties thought it was more important to negotiate the actual control of the plants, however, so that is what was done (the conversion factors remained unchanged).

The convening also serves an important educational value. As the convener discusses the process with the potential participants, he also conveys how convenings typically work, what is expected of participants, how long it will take, the level of commitment that will be required, how the meetings will function, and so on. This can allay considerable anxiety on the part of those who have not played the game before, especially those who are not familiar with the policy process. The parties are therefore more ready to settle down and begin work than if those questions remained unanswered. The parties can also raise any special concerns that may need to be addressed if the negotiations are to run smoothly. ${ }^{66}$

65. In addition, the convening may reveal that an interest consists of many shades of a general interest, each varying in one regard or another. In such a case, the convener may recommend that the interest occupy a certain number of chairs at the table and that the members of the interest select their own representatives to reflect that diversity. In one negotiation, for example, an interest was assigned three seats to reflect the three dimensions along which the members of the group differed. Also, the convening will highlight the issues that need to be resolved, and some of the people contacted in the convening will likely be more interested in some of those issues than others. The convener may then recommend that those individuals participate on work groups that will make recommendations to the full committee; the committee itself usually controls who the members of the workgroups are, but by and large they are open to those who are interested and who possess the requisite technical background. Furthermore, at many of the negotiations, anyone who wishes to speak may do so as long as it does not get out of hand (which occurs extremely rarely). As a result, everyone who is interested in participating generally can participate. In the end, hterally hundreds of people may participate directly in the development of a negotiated rule or other major decision.

66. For example, in one reg neg, a party was concemed that difficult relations it had 
The convening also helps establish a common view as to the issues that will be examined in the process. To an extent, this is the fable of the blind men and the elephant: each has a different view as to the nature of the beast. For example, in one negotiation the facilitator asked each party to describe its view of the issue. The suggestion to do so was immediately challenged by one of the senior menibers of the committee as being unnecessary since everyone present understood the issue. The facilitator persevered and after each meinber had his say, the objector quipped, "See I was right, everyone did understand the issue-only they each saw different issues."

Finally, to ensure that no one is overlooked, and so no one feels left out, the Act provides that the agency should publish a "Notice of Intent" (NOI) in the Federal Register as well as in more mainstream publications such as trade or other specialized journals, where "inere mortals" are likely to encounter the notices. ${ }^{68}$ The notice seeks public comment on a description of the tentative membership ${ }^{69}$ and the issues to be negotiated. ${ }^{70} \mathrm{~A}$ critical aspect of the NOI is that it describes the means by which anyone who feels they would not otherwise be represented by the tentatively identified meinbers can apply for meinbership on the

had in another area might spill over into the negotiations and it needed assurance that that would not happen before it was willing to participate. In another, the internal structure of a caucus had to be carefully thought through before the process would work.

67. Gerald Cormick, a pioneer in the use of mediation to resolve environmental issues, uses a wonderful metaphor to describe the educational value of convening. $\mathrm{He}$ asks rhetorically about what would happen if you were to convene a group to negotiate the rules of football. The Americans would contemplate a game with 11 players using an oblong ball. The Canadians would come prepared to talk about 12 players. The rest of the world would talk about a game that prohibits the use of hands and uses a round ball. The convening would at least highlight the differences so they could be addressed in the negotiations, or the parties could determine what the real issues are given that diversity of perception. See Gerald W. Cormick, Strategic Issues in Structuring Multi-Party Public Policy Negotiations, 5 Negotiation J. 125, 126 (1989); see also supra notes 51-52 and accompanying text (discussing the reaching of consensus in the Coast Guard Vessel Response Plan reg neg).

68. See 5 U.S.C. \& 564(a) (1994).

69. The Negotiated Rulemaking Act contemplates that the specific individuals who are "proposed to represent [the interests which are likely to be significantly affected by the rule]" and "the person or persons proposed to represent the agency" will be named in the notice. Id. Not infrequently, however, the notice only includes a description of the interests, and does not include a list of who will represent the various imterests. The notices should, and usually do, describe who will represent the agency because that can have an important bearing on the nature of the process.

70. See id. 
committee. ${ }^{71}$ Frequently, individuals apply for membership based on the notice and proceed to participate fully. Thus, the process is designed to make as full an effort as is practically feasible to identify those who would be affected by a rule and to ensure that they are represented at the table. ${ }^{72}$

\section{B. Used Only Where Appropriate}

Negotiated rulemaking is not an end in itself, but rather is a tool for making regulatory decisions. Like other tools, it has its time and place and, like other tools, can impose costs and hardships if misused. Thus, negotiated rulemaking should only be employed if its criteria are met, ${ }^{73}$ or if the agency has soine overriding reason to believe that the negotiations will be productive and not harmful.

\section{Process Design}

Like adolescents, every negotiated rulemaking committee is unique. These differences inust be addressed through a careful crafting of the negotiated ruleinaking process. During the design process, certain questions must be addressed, mcluding: What information will form the basis for the negotiation? Where will the information come from? How will the specific facts of the rule or other decision be developed? What scliedule shonld be followed? Should workgroups be formed, and if so, what should they address? Will the workgroups be limited to committee nembers or their designees, or will they include people not on the committee? Who appoints the outside participants? In short, many practical

71. See id. at \& 564(a)(8).

72. Ideally, one would want to be able to walk up to any member of the public and ask what their interest is in the rule, and then point to the representative of that interest on the committee.

73. Congress has, on a number of occasions, required agencies to use a form of negotiated rulemaking to develop specific rules. The provisions were likely inserted at the request of disgruntled constituents who felt the agencies simply did not listen to them sufficiently, and reg neg was a means of forcing the agencies to address their interests. A statutorily required reg neg does not afford the opportunity to determine whether the criteria that predict success are met in individual cases, and an important one of those criteria is that the agency agrees to rely on the process, a reliance which cannot be coerced. With regard to specific criteria, see generally 5 U.S.C. $\& 564$. Perhaps that helps explain why the two recent cases each stemmed from statutorily required reg negs. For discussion of these cases, see supra note 59 and accompanying text. 
issues need to be resolved before the negotiations start if they are to be successful. ${ }^{74}$

\section{Participate Openly and in Good Faith}

It is critical for the agency to participate in the rough and tumble of the negotiations very much like any other participant. If the agency approaches the negotiations as if it has all the answers and only seeks ratification, the negotiation will end with no agreement (since if solutions were so easy, there would not be any need to engage in a negotiated rulemaking ${ }^{75}$ ), and anger on the part of the participants (since they would reasonably feel that they had wasted their time). At the other extreme, if the agency sits back and takes no position, the parties are not likely to reach any agreement-they will talk and talk, but not converge. The reason is that if the negotiations do not reach closure, the agency will issue the rule on its own; the agency's rule will then define the parties" "Best Alternative to a Negotiated Agreement" (BATNA). ${ }^{76}$ The parties will keep talking $\mathrm{m}$ an effort to learn more about what the agency wants or will do on its own. Only then can the parties determine their BATNA, the standard by which they will judge whether a proposal is im their best interest.

The agency's staff plays an essential role during a negotiated rulemaking by taking the lead im crafting the issues and analyzing the data. Indeed, a reg neg is a way for the staff to leverage its knowledge: They can learn an enormous amount by engaging im the soinetimes intense give-and-take of the negotiations and can gain practical insights from the other participants that would otherwise be virtually impossible to develop on their own. In fact, a number of agency officials who have participated in negotiated rulemakings have found the experience extremely rewarding precisely because of its "problem solving" nature and the ability to generate innovative solutions.

74. See Cormick, supra note 67 , at 126 (using a football metaphor to describe the educational value of convening).

75. I recall two very different reg negs in which mid-level agency staff explained their views as to what the ultimate rule would look like; when I asked why the agencies wanted to go forward with the reg neg, I was told by senior officers of both that the staff's views would simply not carry the day and would result in immediate paralysis of the ruleniaking effort-the political process would take over in one form or another.

76. See ROgER Fisher \& WIILIAM URY, GetTing to Yes: Negotiating AgREeMENT WITHOUT GIVING IN 104 (1981). 


\section{E. Consensus}

Consensus is defined by the Negotiated Rulemaking Act as "unanimous concurrence among the interests represented on a negotiated rulemaking committee ... unless such committee-(A) agrees to define such term to mean a general but not unanimous concurrence; or (B) agrees upon another specified definition."77 Basically, this definition means that each interest has a veto over the proposal, and that each interest must determine that the rule, when viewed as a whole, is acceptable ${ }^{78}$ at least as compared to the alternatives. ${ }^{79}$ This forces the parties to deal with each oth$\mathrm{er}^{80}$ and to view the rule as a whole, instead of as a series of separate, freestanding requirements. ${ }^{81}$ This plays an important

77. 5 U.S.C. § 562(2) (1994).

78. For example, a facilitator would like to avoid asking the parties for affirmative assent until the very end of the negotiation. Rather, as the discussions move along, the question would more likely be, "any problems" or "any dissent." Thus, the parties need not display a positive embrace, only that they are willing to go along with the proposal when considered as a whole and when considered in contrast to their BATNA.

79. EPA recently concluded an evaluation of the experience thus far with its Common Sense Initiative. See supra note 40 and accompanying text. A criticism of the CSI process that runs throughout the evaluation reflects the importance of this definition of consensus:

Participants in CSI perceive that consensus has been defined as unanimity, thus providing each individual with a veto power. This lias hampered progress and many suggested that consensus be redefined to require less than complete agreement by all participants. This would allow an idea to move forward, even if some participants did not favor it, but could "live with it."

CSI REVIEW, supra note 40 , at iii. This CSI definition of consensus requires every individual participant to express affirmative support for the agreeunent. The definition in the Negotiated Rulemaking Act, however, contemplates that each interest must concur, recognizing that individuals within each interest may have some reservations, but that the interest, when considered as a whole, supports the decision. In addition, the overall affirmation is to the decision as a whole, not the individual pieces, so that the measure, all things considered, is whether each interest can "live with" the decision. Id. CSI clearly would have benefited by learning from the reg neg experience.

80. If the parties voted, those in the majority would have no reason to hear out those in the minority on an issue. The curt answer to someone's proposal would be a simple, "Let's vote." If, however, consensus must be reached, the people in the majority must grapple with the minority's issues of concern.

81. When consensus is reached on the entire rule or policy under deliberation, each party needs to understand that they will not be thrilled with each and every provision. Instead, each participant needs to focus on the elements of importance to its constituency. Deciding whether to concur in a negotiated rule is a bit like buying a house: a house may have many nice features but there is always something about it that is not as nice as some other house. You cannot, however, buy a house that has one feature from one house and another feature from another house, and so on. You have to buy the whole house, warts and all. So too with rules. The reason that this analogy holds true is that 
role in knitting the committee together into a cohesive group with a common goal: developing an acceptable rule. Thus, tinkering with the definition of consensus entails a very high risk of failure and dramatically changes the functioning of the committee.

The dynamics of the process change inarkedly if either the definition of consensus is modified to require less than unanimity or, if no atteinpt is inade to reach full closure, to require a coinmitnent to adhere to the agreement. During the discussions themselves, the parties are likely to espouse their positions-the pohicies they have advocated publicly-as opposed to developing their underlying interests or needs. This is because if the parties do not control the outcoine in the form of an agreennent in which they concur, they cannot afford to back off from their adversarial positions. Although the rancor nuay be reduced, especially after multiple ineetings, parties are likely to continue to maintain an adversarial stance, attempting to influence the ultimate decision by exaggerating the facts and policy concerns. Moreover, it is difficult to develop sophisticated trade-offs. For example, if a party is willing to accept solnething only on the condition that another condition is inet (e.g., it could accept a low limit if phased im over a period of time) and that party does not control whether the condition will in fact be fulfilled (e.g., whether the phasing will be permitted), the party is not likely to agree to the initial result (e.g. the low limit) or even to admit that it is possible. Further, participation by a party does not ensure that that party will accept the final decision or not take action to stop it; thus, the agency and others may have learned something, but it is wrong to assume that simply because someone participated they will not take subsequent action to change the outcoine. And, indeed, the process may actually increase frustration if parties are asked their views and then are ignored.

\section{F. Early Implementation}

Once the committee has reached a consensus, the agency needs to act expeditiously to innplement it. If any new issues arise during its review, the agency should raise thein with the committee

different parties value elements of each rule differently. Requiring parties to view the rule as a whole, however, forces the parties to address the needs of each interest and then to achieve a consensus. 
to gain its collective insight. If instead the agency second-guesses the committee or takes a long time to review the materials, the initial support can wane. This undoubtedly is a form of the "compression" that Professor Coglianese inentions, but by that time very little usually reinains to be done. ${ }^{82}$

\section{SUPPORT FROM THE CLINTON ADMINISTRATION}

Perhaps because of negotiated rulemaking's early success ${ }^{83}$ in addressing some coinplex, controversial rulemakings and perhaps because the inclusive nature of consensual processes comports with its political bent, the Clinton administration has voiced strong support for the use of reg neg and other consensual processes. President Clinton's Executive Order on White House oversight of ruleinaking encourages agencies to use consensual processes, especially negotiated rulemaking, for developing rules. ${ }^{84}$

The Vice President's National Performance Review (NPR) noted:

The traditional model for rulemaking is that of agency experts deciding the best way to regulate, offering the public an opportunity to comment on the agency's proposed rule or to object to its adoption, and then issuing binding rules telling regulated entities what to do. Even if the agency experts clioose wisely, the traditional model has very little buy-in from outside the agency, which undermines the rule's effectiveness. This traditional process encourages adversarial, uncooperative beliavior on the part of private industry or others who might be affected by an agency's decisions, which frequently leads to protracted litigation. Agencies routinely find themselves under attack from various private parties who are unhappy with the rule. This has been particularly true in controversial areas such as environmental regulation or the liealth and safety of workers. ${ }^{85}$

The NPR's recommendation for rectifying this problem is to "increase the use of negotiated ruleinaking."

82. See Coglianese, supra note 49 , at 1285-86.

83. See supra notes $49-53$ and accompanying text.

84. See Exec. Order No. 12,866, 3 C.F.R. 638 (1993), reprinted in 5 U.S.C. $\S 601$ (1994).

85. OfFice of the Vice PResident, Accompanying Report of the National PERFormance REVIEW: IMPROVING REgULATORY SYSTEMS 29 (1993) [hereinafter IMPROVING REGULATORY SYSTEMS].

86. Id. at 32 . 
that the President encourage agencies to use reg neg and urge them to identify at least one candidate for the process. ${ }^{87}$ It also suggests that "[t]he administration should facilitate efforts to use reg neg by identifying and removing any administrative barriers to its use." the heads of agencies directing that they use reg neg at least once ${ }^{89}$ - probably on the theory of "try it, you'll like it." Sparked by this interest and high-level attention, a number of agencies that had not previously used reg neg have now either actually used it or are at various stages of starting the process.

NPR likewise recommended that the President encourage agencies "to use alternative means of dispute resolution." year ago, the President issued an Executive Order on "Civil Justice Reform." ${ }^{92}$ Although primarily aimed at hitigation im federal courts, the Order has several important ramifications for administrative ADR. It provides:

Where the benefits of Alternative Dispute Resolution ("ADR") may be derived, and after consultation with the agency referring the matter, litigation counsel should suggest the use of an appropriate ADR technique to the parties. ... It is appropriate to use ADR techniques or processes to resolve claims of or agamst the United States or its agencies, after hitigation counsel determines that the use of a particular technique is warranted in the context of a particular claim or clains, and that such use will materially contribute to the prompt, fair, and efficient resolution of the claims. ${ }^{93}$

87. See id. at 32 .

88. Id.

89. See Memorandum for Executive Departments and Selected Agencies [and the] Administrator of the Office of Information and Regulatory Affairs, 58 Fed. Reg. 52,391 (1993).

90. The Administration was not entirely consistent in this regard, however, a fact which did not escape the attention of the agencies. While it paid lip service to encouraging agencies to use consensual processes, it sinultaneously made it much more difficult for agencies to obtain the requisite charters under the Federal Advisory Committee Act that are necessary for reg negs and other consensual processes that culminate in a commitment.

91. IMPROVING REGULATORY SYSTEMS, supra note 85, at 3.

92. See Exec. Order No. 12,988, 3 C.F.R. 157 (1996), reprinted in 28 U.S.C.A. $\$ 519$ (1997).

93. Id. 


\section{Current Performance-So Where ARE We Now?}

With such high level support from the White House, and with the EPA using consensus or public participation processes as an integral part of virtually all of its major initiatives, ${ }^{94}$ it might logically be said that administrative ADR has never been hardier. The adolescent would surely get an A, with honors to boot.

In one regard, that is certainly true. The landscape of rulemaking and other forms of policy development has been transformed. It is now custoinary for agencies to invite direct public participation or stakeliolder involvement before taking regulatory action. Indeed, the techniques described in Appendix A indicate the rich variety of processes that have emerged and the full range of circumstances in which they are employed. The use of these processes has mjected a significant degree of democracy imto the regulatory process that was previously lacking in more hierarchical decisionmaking. This effect cannot not be overemphasized. On the other liand, there is less good news in the use of consensus processes to make specific decisions that are actually iniplemented.

There are some very bright spots, liowever. The Department of Transportation and its various auxiliary agencies have widely embraced negotiated rulemaking and have used it to develop a variety of rules. Indeed, both the Federal Aviation Administration and the Federal Railroad Administration have estabhished standing committees that consider a range of issues.

Alas, such is not the case generally. While there is much bravado, there is less substance. For example, the EPA has not initiated a single negotiated rulemaking during this administration, presidential directive notwithstanding. This appears symptomatic of the current state of affairs. Briefly stated, two things seem to be happening: First, the decisions to implement consensus-type processes are being made at lower levels in the agencies, and many career agency officials seem to feel uncomfortable with processes that lead to a commitment. Second, agencies are siniply not paying careful attention to the parts of the process that have made it so successful..$^{95}$

94. EPA initiatives making use of public participation include the Agency's Common Sense Initiative, Project XL and "Brownfields." See supra note 41 and accompanying text.

95. See supra note 73 and accompanying text. Like an adolescent, the agencies may be sloughing off various procedures that were used previously in part because they do 


\section{A. Convening}

Too frequently, the crucial convening stage of a consensus process has been either ignored or short-circuited. For example, some agencies have simply invited anyone who wanted to attend meetings at which the potential for conducting a reg neg or other consensus process would be discussed. The agencies did not expend the effort to identify the parties or the issues. This is unfortunate, as careful selection of interested parties and the issues both ensures the broad-based participation necessary to legitimize the process (and to ward off judicial review) and defines the issues. For example, at least some of EPA's CSI initiatives were not convened in the common understanding of the process, ${ }^{96}$ and many felt that the composition of some of the committees may not have been fully appropriate and that they languished before gaining direction. Suitable convening could have remedied that. ${ }^{97}$ Further, a proper convening also greatly expedites the process once it starts.

In some instances, agencies have undertaken a brief convening on their own in an effort to save time and/or money. ${ }^{98}$ While it

not understand why they are important and in part to experiment with new approaches. Successful adolescents leam and build both on what went before and on their own experimentation. Currently there is enough discussion and whispers of concern that the examination may soon take place.

96. Some on the EPA staff were actually hostile to the notion of convening, declaring it "old fashioned."

97. The CSI evaluation has two interesting insights along these lines:

While the overall goals of CSI were articulated by the Administrator in initiating the program, specific objectives and expectations for the program were not. Instead of encouraging out-of-the-box thinking as hoped, this has led to delays ... as [participants] tried to figure out what EPA wanted or would accept instead of inventing their own priorities and processes. While this has improved as the subcommittees have set their own agendas, they still look to EPA for more leadership.

CSI Review, supra note 40 , at ii. A thorough convening develops a common understanding before the parties come together. That way, the negotiation process can be productive from the outset.

The evaluation also pointed out that:

additional preparatory work as new sectors are selected would be beneficial.

EPA should conduct some background research with potential participants to learn about opportunities for and barriers to improved environmental performance. This could also serve to identify potential participants and to ascertain their levels of interest and commitment to a process like CSI. Those participants who would need technical assistance could begin to receive it early, perhaps before the formal stakeholder group convened.

Id. at iii.

98. In an effort to reduce the out-of-pocket costs of convening, some agencies have 
surely works for agencies to do their own convening (although it usually works better to have someone from outside the agency do it, precisely to develop a more candid response from those in the private sector and to provide objective advice ${ }^{99}$ ), the convening still needs to be complete and thorough. Thus, more attention should be paid to the convening stage of all consensus processes. ${ }^{100}$

More attention should also be paid to the actual process itself. In too many instances the terms "consensus," "stakeholder imvolvement," "public participation," or the like have been mvoked as if they all referred to the same process and outcome so that their mere incantation meant that everyone's views were incorporated into a decision and that everyone accepted the results. There has been too little of the painstaking, lawyerly approach of carefully designing a system. The processes developed over the years that proved so successful were the result of an enormous amount of debate, discussion, and scholarship, building on the experience of similar or analogous programs. Each stage was carefully developed.

used experienced personnel from other agencies as the convener. This has appeared to work quite well, especially when the convenor collaborates with the person who will ultimately serve as the facilitator.

99. It is sometimes alleged that a convener from the private sector may have a conflict of interest since he would be inchined to recommend going forward with a reg neg on the expectation that he would then serve as its facilitator; the bias, therefore, would be to get more business. While there is undoubtedly at least some merit to the concern, there are strong countervailing reasons to have the same person do both. First of all, the neutral learns a great deal about the issues and the parties during convening that can then be put to use during the actual negotiations; if another person serves as the facilitator, much of that knowledge either must be re-leamed or, more likely, the newcomer will simply have to do without some of that insight because the relationship between the facilitator and the parties is different than that of a convener and a prospective party. Second, if a negotiation is not in fact appropriate, so that it is unlikely the parties will reach agreement or some harm may be done, and the convener and the facilitator are the same person, everyone knows whom to blame: there is definite accountability. If they are different, each can point to the other if the reg neg fails, thereby diluting accountability. Since no neutral can guarantee that the parties will converge to agreement, it is not the case that sonie neutral-convener or facilitator-should always be held responsible if the committee fails to reach agreement. Rather, the accountability arises only when the circumstances were such that the negotiations should not have moved forward in the first place.

100. There is, for example, some controversy over the "convening" stages of the EPA's Project XL program. See, e.g., Cindy Skrzycki, Critics See a Playground for Polluters in EPA's XL Plan, WASH. POST, Jan 24, 1997, at D1 (discussing how the inplementation of new regulatory approaches can make it difficult to convene an EPA project). A rigorous attention to who sits at the table and what issues are on it would go a long way toward deflecting some of this criticism. 
Very little of that has been done for the new initiatives, and the deficiency shows. ${ }^{101}$

\section{B. Level of Decision}

There has been a "top down" encouragement to use consensus processes in this administration, including directives from the President, Vice President, and agency heads. While this encouragement was surely well intended, it has led some program managers to use reg neg or other consensus processes siniply for the sake of doing so, or to fulfill a political requirement even if a consensus process is an inappropriate tool. To be sure, the fit was certainly good in some instances; in others, lowever, the agency's approach to the process was less than enthusiastic.

While overall support from senior officials has been high, the day-to-day implenientation of reg negs and other forms of consensus has devolved to lower levels within the agencies. Before, fairly semior officers would nuake the decision to use a reg neg based on their view of the surrounding political controversy, the need to develop information that was mainly in the private sector, the need to tap the insights and expertise of the private sector, and various other motivations. Surely one of the animating features of the decision was that the agency staff alone did not have sufficient horsepower to write the final rule. ${ }^{102}$ Now, however, it appears

101. As one reviewer-the mother of several small children-commented, in too many instances the agency was indeed acting like an adolescent's strong desire to do it "By myself!" Although the phrase itself is probably better befitting a two-year old, the point is that the processes are used in new ways without carefully analyzing what worked and why. Although such experimentation can help determine what does and what does not work in various situations, and hence ultimately lead to better practice, it would be more reassuring, and surely more efficient, if the experimentation were done knowingly.

For example, it is relatively striking that the CSI evaluation makes no mention whatsoever of EPA's significant experience with negotiated rulemakings. See supra note 40 and accompanying text. Perhaps, however, it should not be so surprising that the evaluation would not make mention of it, for the agency itself seemed to pay so little heed to its own experience.

102. Lest there be any confusion here, the agency staff plays a critically important role in raising the issues, focusing the discussion, working out the various options, and generally being a leader. What this sentence means is simply that in many of the highly controversial rules, it is important to gamer the insights and participation of those affected if the rule is to: 1) be developed in a timely fashion; 2) take account of all relevant information; and 3) be inplemented on time. Otherwise, the rule might be held up in internal development and White House review, judicial review, or review at the agency itself. Rulemaking is, after all, the political side of agency action, and as Louis Jaffee 
that fairly uniformly across the government, the decisions to implement these programs are being made on a program basis; a fair amount of resistance to the use of a consensus process has developed at that level. ${ }^{103}$

\section{Consultation, not Consensus}

A negotiated rulemaking forces the parties to bring an enormous amount of practical information to the table and hence expands the data base on which to build a regulation. The practical insight contributed by those with first-hand experience also allows agency staff to focus resources on areas with the greatest potential payback. While these may seem to be considerable benefits of the process, a fair number of agency personnel feel it is inconsistent with their prerogative to share the decision with others around the table. ${ }^{104}$

For example, the Steel Erection Negotiated Rulemaking Advisory Committee (SENRAC) at OSHA developed a rule addressing the erection of steel buildings and other structures. ${ }^{105}$ When the

pointed out in his last major article, political controversy continues to swirl around an agency's exercise of its rulemaking authority. See Louis L. Jaffee, The Illusion of the Ideal Administration, 86 HARV. L. REV. 1183, 1191 (1973).

103. For example, within the past six months, I am aware of at least three agencies which were in various stages of considering using or completing reg negs that had been convened in which staff opposed "sharing" decisions as inconsistent with the role of the agency. In two of those, the agency had been unable to fulfill its task of developing suitable regulations, and yet the notion of using reg neg was perceived as threatening to the prerogative of the agency-never mind that it had never been exercised due to political controversy and the lack of suitable information on which to base the regulations.

104. For example, in a recently issued set of recommendations, the Public Sector Critical Issues Committee of the Society of Professionals in Dispute Resolution stated, in bold:

Before a governinent agency or official decides to sponsor an agreement seeking process, it should consider its objectives and the suitability of the issues and circumstances for negotiation. In particular, before the sponsoring agency convenes a collaborative process, it is essential for the agency to determine internally its willingness to share control over the process and the resolution of the issue.

Public Sector Critical issues Comm., Society of Professionals in Dispute ResoLUTION, BEST PRACTICES FOR GOVERNMENT AGENCIES: GUIDELINES FOR USING COLLABORATIVE AGREEMENT-SEEKING PROCESSES 5 (report accoinpanying Recommendation 1) (Jan. 1997).

As an example of the contrary attitude, one branch chief endorsed a consensus approach by saying that the committee should make no mistake that she and she alone had the authority to make the relevant decision, but that the decision would not be invalidated simply because the others agreed with her.

105. See Steel Erection, 62 Fed. Reg. 21,967 (1997) (to be codified at 29 C.F.R. pt. 
rulenaking started, the primary, indeed virtually the only issue in contention was how high an ironworker could climb before having to be secured or otherwise protected froin falls. It became clear as the negotiations progressed that many other factors would contribute significantly to a safer work place.

Although the fall protection scheme in SENRAC's recommendation is based on an earher standard developed by OSHA itself, and in many ways is inore stringent than that standard for comparable work, the standard has been opposed internally by OSHA staff. This opposition has arisen despite the fact that OSHA had representatives on the committee (one fornally, the other as counsel) through whom its staff could have voiced its concerns, and despite the fact that senior officials and committee members who strongly advocated safety concurred in the standard. The staff has delayed adoption of the standard by 18 months, just as they did in OSHA's previous reg neg on MDA. This is certainly not an example of the staff's being frozen out of the decisionmaking process, since it could have fully participated both in internal caucuses and in the negotiating sessions.

Because of the staff's feeling that it must preserve its authority to ensure a "correct" decision on the issue, ${ }^{106}$ there has been a reluctance to embrace consensual processes im which the outcome is an agreement-a commitment on the part of private sector and agency alike to abide by the agreement. Just why that resistance has grown in this administration is difficult to explain. ${ }^{107}$ Instead, there has been a broader endorsement of "consultative" processes or "consensus recommendations" in which the committee provides advice to the agency for its due consideration. As dis-

1926) (proposed Apr. 25, 1997) (describing the history of SENRAC and the development of the rule).

106. In many of the instances in which reg neg would be an appropriate tool, the notion of "control" is not so clear: Although the agency may clearly have the authority to issue the rule or otherwise take the governmental action; it may lack the power to do so, when private parties and other agencies have the political power to stop the agency from achieving its goals. In such cases, agency "control" over a rulemaking is more illusory than real.

107. Several fairly senior agency officials from diverse agencies have opined informally that they think there is less substantive guidance within this administration than in its predecessors. Mid-to-senior level career officials therefore feel more vulnerable about having their decisions second-guessed. They are simply not sure what will be acceptable and hence are reluctant to engage in a dialogue if it leads to a commitment, since they would then have to sell it to their managers. 
cussed above, ${ }^{108}$ many of the benefits of the process are lost by this change.

\section{THE Difficulty with Evaluations}

Alas, this mathematician turned lawyer finds himself a curmudgeon with respect to the evaluation of reg negs and other consensual processes. My concern surely does not stem from a fear that reg negs will not hold their own or that other consensus building procedures will not prove beneficial when compared to their adversarial counterparts. Rather, it stems from the difficulty of developing a suitable measure for "as compared to what." Reg negs are intense activities: participating in one can be expensive $^{109}$ and time-consuming, and requires participants to make hard choices. ${ }^{110}$ Since a reg neg is such a focused activity, it is relatively easy to tally the expenses and time involved in participation. Conventional notice-and-comment rulemaking for significant rules, on the other hand, is far more diffuse. These rulemakings extend over a longer period and people tend not to keep score nearly as carefully. Thus, the data on which to base comparisons is likely to be flawed. Moreover, there is a real difficulty in comparing two rules in being sure that you are measuring differences in the process and not differences in the underlying pohtics of the matter. My concern, therefore, has been that analysts would seize on the hard numbers, which would look high, without considering fully what goes on in a routine rulemaking. We have also seen repeated examples of an agency's staff forgetting that an issue has been on its docket for a very long time, all the while incurring time and expense. Further, agencies often use reg neg for atypical rulemakings precisely because they fear the rule will not get done in a reasonable time.

Neil Kerwin and Laura Langbem's study of reg negs at EPA should help address this concern. ${ }^{11}$ They conducted many inter-

108. See supra Part III.E-F.

109. See KERWIN \& LANGBEN, supra note 47 , at 35 ("Participation in negotiated rulemaking emerges as quite costly, with the impact appearing to fall disproportionately on smaller organizations."). Indeed, finding ways to defray some of the costs of participation is a major challenge of many reg negs.

110. See Ellen Siegler, Regulatory Negotiations: A Practical Perspective, Envtl. L. Rep. (Envtl. L. Inst.) 10,647, 10,650 (Oct. 1992).

111. See KERWIN \& LANGBEN, supra note 47, at 47-48. Note, however, that Kerwin and Langbein say that these results are tentative, and that conclusions cannot really be 
views of the participants in reg negs and have identified a number of rules that they regard as "similar" enough to merit comparison. ${ }^{112}$ Their final report should be enormously helpful.

In my skepticism over evaluations, it never occurred to me that the bean counters would count the wrong beans, but I fear that is what has happened in Professor Coglianese's study. Rulemaking is an inherently political activity; to understand a negotiated rulemaking, both the political setting im which it operated and the internal dynamics around the rule itself must be examined. Unfortunately, many of the empirical observations are too limited to be of much value is assessing the merit of reg negs.

First, Professor Coglianese observes that reg negs have only been used for a tiny fraction of all rules. ${ }^{113} \mathrm{He}$ sees this lack of pervasiveness as an mdicator that the reg neg process itself is flawed. Rather, the process needs to be put im perspective. It is unquestionably an imtense process, and hence it should be used ouly im those instances in which its benefits merit the expenditure of the resources: ${ }^{114}$ issues that are complex and controversial, but nevertheless negotiable. ${ }^{115}$ These are the rules that so often stall an agency while the political forces work their will. A reg neg provides a forum for those forces so that while developing the rule, the committee is also developing a pohtical consensus. At any given time, there are not likely to be many issues within that category. Reg neg is a tool that should only be used in appropriate situations. Hammers and screwdrivers are used far more than socket wrenches, but those wrenches form an essential part of any worker's toolbox. This both explains the relatively sparse use of reg neg and the reason many of the rules that have been the subject of reg negs take a long time-they are the big ones.

The primary measureinent of the reg negs is also fundamentally flawed. One cannot simply count days without any understanding of where a reg neg fits imto the overall rulemaking process and purport to understand anything about reg negs tliemselves. It was interesting to see the long periods between initiation

drawn until Phase Two of their study is completed. See id.

112. See id. at 2.

113. See Coglianese, supra note 49 , at $1274-78$.

114. It would therefore not be appropriate to use reg neg for run-of-the-mill type cases.

115. For instance, in the current political environment, it would be futile to attempt to negotiate an agreement on virtually any aspect of the abortion issue. 
of the rulemaking and its final Federal Register notice in some of the reg negs that he lists, ${ }^{116}$ and the observation certainly forces one to ask what is going on. Unfortunately, that question was neither asked nor answered by Professor Coglianese. The answer again is the political setting of the process. For example, the Coast Guard decided to use negotiated rulemaking after its initial hearing on an advance notice of proposed rulemaking (when the clock had started running) precisely because it encountered such high seas: the level of controversy over the proposal was significant indeed and the deadline was sliort. The committee it empaneled came up with a solution in record time, and the Coast Guard met its schedule; the interim rule was later incorporated into another, broader rule (note the clock is still ticking). Thus, the time-clock evaluation is meaningless in light of the actual process. ${ }^{117}$

Appendix B provides an explanation for all but one of the reg negs in Professor Coglianese's table that took more than 1,000 days. When one goes beyond the docket sheets and understands what actually happened im those proceedings, the only conclusion can be that reg neg is a powerful process indeed. His analysis does, however, raise several important issues: why is it that some agency staff feel so threatened by commitment when in fact participating in a negotiation can actually lead to better solutions? And, why is it that OSHA's staff regularly takes 18 months to review a consensus?

\section{CONCLUSION: WHAT IS THE GRADE?}

It is currently popular to talk in terms of consensus and of public involvement, in terms of "public-private partnerships," and of community involvement. Properly executed, these processes can greatly expand an agency's knowledge and insight into an issue on which it must act, expedite the agency's work by highlighting the contentious issues to which the agency can devote its resources,

116. See Coglianese, supra note 49 , at 1281 tbl.3.

117. If one wanted an even more extreme example, the Federal Aviation Administration had published two Notices of Proposed Rulemakings on Flight and Duty Time, but was not able to issue the rule. The FAA tumed to reg neg, largely in desperation, and was successful. Counting only the days from the first to the last notice would conceal the contribution of reg neg to its resolution and make the process appear very long. This assertion is supported by many discussions between the author and Neil Eisner, Assistant General Counsel for Regulation and Enforcement of the United States Department of Transportation. 
lead those affected to accept decisions they might otherwise oppose, develop political support for decisions that would be played out in many fora, and resolve specific issues that would otherwise end up in court or Congress. The resulting regulatory actions often are more creative and subject the issues to more stringent scrutiny at lower costs than actions taken through more traditional means. In short, the regulatory actions are often simply better by virtually any measure. These are, indeed, powerful tools.

A number of new approaches have been tried, and proven approaches have been tinkered with im an attempt to see what is necessary and what is not. These processes clearly work best when those implementing thein pay close attention to the factors that have emerged from a generation of experience. To secure their wider endorseinent, it will be necessary to convince the agency prograin managers that it is in their interest to be full participants in processes that lead to a commitment. Program managers must reahize that through consensus processes, they learn a huge amount and can develop extraordinarily sophisticated decisions that otherwise would not be within reach. Without this support, unfortunately, these potentially powerful tools will not be fully used and those used in their stead do not have nearly the same benefits.

Perhaps just as adolescents shy from commitment but soon emerge from their hesitancy to undertake wholesome relationships, so too will the current experience with processes that are short of consensus lead to ones that embrace it so that we can gam their full potential. 
APPENDIX A

\begin{tabular}{|c|c|c|}
\hline INFORMATION EXCHANGE & Dialogues & Consensus Decisions \\
\hline $\begin{array}{l}\text { - Single interest consulta- } \\
\text { tions } \\
\text { - Public participation } \\
\text { Public learing } \\
\text { - Public meeting } \\
\text { - Informal processes } \\
\text { which provide opportu- } \\
\text { rity to make reviews } \\
\text { known as to a proposal } \\
\text { - Information or idea } \\
\text { exchange } \\
\text { - Opportunity to express } \\
\text { concerns } \\
\text { - Raise issues that must } \\
\text { be considered in regu- } \\
\text { latory action } \\
\text { - Focus Groups } \\
\text { - Greater exchange of } \\
\text { views } \\
\text { - Citizen Advisory Boards } \\
\text { - fornm to express needs, } \\
\text { concerns } \\
\text { - Workshops } \\
\text { - Reactions to proposed } \\
\text { rules, other policies } \\
\text { - Raise issues to be con- } \\
\text { sidered in regulatory } \\
\text { action } \\
\text { - Explain how proposed } \\
\text { action would work; } \\
\text { provide assurances } \\
\text { - Forums } \\
\text { - Opportunities to share } \\
\text { views, perspectives; } \\
\text { make informal, non- } \\
\text { consensual recommen- } \\
\text { dations } \\
\text { - Roundtables } \\
\text { - Addressing more com- } \\
\text { plex factual// policy } \\
\text { issues } \\
\text { - }\end{array}$ & $\begin{array}{l}\text { - Scoping sessions } \\
\text { - Policy Dialogues } \\
\text { - Recommendations for } \\
\text { statutory or major policy } \\
\text { clrange } \\
\text { - Teehnical workshop or } \\
\text { joint fact-finding on sci- } \\
\text { entific, technical, or other } \\
\text { data to be used in other } \\
\text { proceedings } \\
\text { - Task Forces } \\
\text { - Advisory Committees } \\
\text { - Citizen Advisory Boards } \\
\text { - provide advice/recom- } \\
\text { mendations }\end{array}$ & $\begin{array}{l}\text { - Negotiated Rulemaking } \\
\text { - Consensus permits } \\
\text { - Plan allocating responsi- } \\
\text { bilities among agencies or } \\
\text { levels of governments } \\
\text { - Settlement of enforcement } \\
\text { actions } \\
\text { - Among multiple } \\
\text { defendants and agencies } \\
\text { - Involving other stake- } \\
\text { holders/affected inter- } \\
\text { ests }\end{array}$ \\
\hline
\end{tabular}


APPENDIX B

An Analysis of the Reg Negs From table 3 of

Professor COGLIANESE

AGency Negotiated RULEMAKING COMment

DOT Flight \& Duty Time

OSHA Benzene

EPA Nonconformance Penalties

EPA Emergency Pesticide Exemptions

EPA Farmworker Exposure to Pesticides

This was only a partial reg neg: the ageney initially sanctioned it, but later refused to participate or even formally acknowledge a connection with the dialogue and its rule. OSHA itself announced an ambitious schedule for developing the standard and inissed its deadline by years; the reg neg had no effect on that delay. It should be noted, however, that the OSHA staff has said the committee's deliberations were very helpful and, importantly, it should also be recognized that the benzene standard was OSHA's first major health standard that did not result in immediate judicial review.

cides

The reg neg itself only lasted 3 or 4 months before the farmworker contingent walked out, thereby ending the reg neg. Thus, the remainder of the time was spent developing a rule through traditional means, not by a reg neg. This proves the opposite thesis. Moreover, one should compare the draft rule that was on the table when the reg neg ended with what ultimately emerged from the agency; it was far more protective. Finally, EPA has said it learned an extraordinary amount during the process that influenced its entire regulatory approach in the area.

OSHA MDA

The reg neg committee reported out an agrecment in punctual time. Internal OSHA analysis has shown that both the time and cost involved in developing this standard was roughly half that of a very similar standard developed by conventional means. The extraordinary time involved was consumed by internal OSHA review of the consensus that was reached in the reg neg. That review was quite controversial 
among the participants and was largely attributed to a strong case of "notinvented-here." The delay did not stem from the reg neg. Indeed, a very similar phenomenon is occurring at the moment with respect to the steel erection-Subpart R-standard.

EPA Wood Stoves

EPA Underground Injection of Hazardous Wastes

This reg neg did not reach agreement because of a fundamental disagreement over the interpretation of the underlying statute that required an authoritative decision by the DC Circuit to resolve; that dispute was known from the outset and the parties attempted to negotiate around it, but in the end the differences needed to be resolved. The rule EPA published was developed in the reg neg.

EPA RCRA Permit Modifications

DOT/FAA Nondiscrimination on basis of handicap in air travel

This committee did not reach agreement, so that the long delay is attributable to the agency itself - or rather the two agencies since they disagreed with one another - working out the reg, not to the committee. It should be noted that many of the parties to this reg neg subsequently requested DOT to use reg neg to develop future rules of interest to them, precisely because they thought it was effective.

NRC Records related to licensing

EPA Asbestos-containing materials in schools

This case resulted in judicial review of the rule. The committee did not agree, however, not to seek review, so the review was not surprising.

Education Assistance to meet special ed. needs

EPA Equipment leaks

The equipment leaks regulation was part of the broader rule governing hazardous organic chemicals, known as the HON (Hazardous Organic National Emission Standard for Hazardous Air Pollutants). This part of the rule was completed years before the rest and simply had to await the other parts 
before it was published. There is testimony, however, that most firms were complying with the rule long before it was in effect. Any delay here was caused by the traditional process, not reg neg.

DOT Handicapped Parking

Agriculture Sheep scrapie

Once the committee got involved in the issue, everyone realized it was far more complex than originally believed. Thus much greater effort was needed to craft the rule. Note also that the subject is related to the now prominent issue of mad cow disease.

Education Perkins vocational \& applied technology regulations

DOT Transportation for individuals with disabilities

EPA Clean Fuels (Oxygenated and Reformulated Gasoline)

The committee completed its work in an incredibly short time given the magnitude of the task. During the Presidential campaign, however, the Bush administration was pressured to change the proposed rule from the one developed by the committee; then the next administration changed the proposal further. Thus, the delay came not from the committee but from political directives to change it. No rulemaking, be it reg neg or otherwise, is fully immune from the political process. The judicial review stemmed from the fact that the final rule was not as proposed by the committee; the difficulty with the WTO is with the statute; neither come froin the reg neg. Indeed, the fact that the rule was negotiated helped ward off additional changes.

Coast Guard Oil spill response plans

This enormously complex undertaking was convened because the Coast Guard had to issue a binding rule in a very short period. From the publication of a notice of intent to form a committee to a NPRM was a little over 6 months; an interim final rule was in place in another 6 months. This is an extraordinarily short schedule. Portions of the overall requirements under the statute 
were not the subject of the negotiations, however, and proceeded by normal rulemaking; once they were completed - years later - the interim final rule was incorporated into the overall scheme. Far from delay, this rule proves that reg neg can be an expeditious process.

$\begin{array}{cl}\text { EPA } & \text { Coke ovens } \\ \text { FCC } & \begin{array}{l}\text { Non-voice, low earth orbit satel- } \\ \text { hites }\end{array} \\ \text { Farm Credit } & \begin{array}{l}\text { Assessment and apportionment of } \\ \text { expenses }\end{array}\end{array}$

Education Higher Education Amendments of 1992

EPA Disinfectant byproducts

EPA Wood furniture

Education Direct student loan regulations

Education Guaranty agency reserves

Education Helping disadvantaged students

HHS/DOI Indian self-determination HUD

Coast Guard Chicago drawbridge operations
The reg neg itself lasted only 6 months before an agreement in principle was reached; EPA took a year to craft the agreement into an 800-page NPRM which was then signed by the committee. Given the magnitude of the NPRM and of the scientific controversy surrounding this issue, completion of the process in the less than four years is an enviable accomplishment.

This rule was subject to judicial review, but the rule as issued was not as recommended by the committee.

Operating Subsidies for vacant public housing units 